\title{
Pertambahan Bobot Badan dan Feed Conversion Rate Ayam Broiler yang Dipelihara Menggunakan Desinfektan Herbal
}

\author{
Yonas Adytia Nugraha, Khoirun Nissa, Nikmah Nurbaeti, Fadlu Muhammad Amrullah, \\ Dian Wahyu Harjanti
}

Program Studi Peternakan, Fakultas Peternakan dan Pertanian, Universitas Diponegoro

Corresponding author : yonasnugraha58@gmail.com; dianharjanti@undip.ac.id

\begin{abstract}
Residu bahan kimia dalam produk pangan asal ternak merupakan ancaman serius bagi keamanan pangan dan kesehatan. Desinfeksi merupakan program biosecurity yang wajib dilaksanakan dalam proses pemeliharaan ayam broiler, oleh karena itu, untuk menjaga keamanan produk, diperlukan inovasi dan alternatif untuk menggantikan desinfektan kimia sintetis yang sampai saat ini masih digunakan oleh peternak. Daun babadotan (Ageratum conyzoides) diketahui memiliki daya antibakteri yang mampu menghambat perkembangan dan membunuh bakteri patogen. Tujuan dari penelitian ini adalah untuk mengetahui pengaruh penggunaan desinfektan herbal berbahan dasar ekstrak daun babadotan terhadap produktivitas ayam broiler yang diketahui berdasarkan pertambahan bobot badan harian (PBBH) dan konversi pakan (Feed Convertion Rate, FCR). Penelitian ini menggunakan desinfektan herbal konsentrasi $1 \%$ dan $1,5 \%$, serta desinfektan sintetis komersial 1,5\% sebagai pembanding. Hasil penelitian menunjukkan bahwa PBBH ayam broiler yang dipelihara dengan menggunakan desinfektan herbal dan sintetis tidak berbeda $(\mathrm{P}>0,05)$. Nilai PBBH desinfektan herbal $1 \%$ dan 1,5\% adalah 35,11 dan 33,69 g/ekor/hari, sedangkan desinfektan sintetis 32,75 g/ekor/hari. Nilai FCR ayam pada pemeliharaan menggunakan desinfektan herbal juga menunjukkan hasil yang sama $(\mathrm{P}>0,05)$ dengan desinfektan sintetis. Nilai FCR desinfektan herbal $1 \%$ dan 1,5\% adalah 1,6 dan 1,67. Sedangkan FCR desinfektan sintetis sebesar 1,63. Berdasarkan data tersebut disimpulkan bahwa desinfektan herbal ekstrak daun babadotan dapat digunakan dalam kegiatan biosecurity di peternakan ayam broiler sebagai pengganti desinfektan sintetis.
\end{abstract}

Keywords: desinfektan herbal, biosecurity, produktivitas, ayam broiler

\section{PENDAHULUAN}

Di Indonesia terdapat banyak tanaman obat yang beragam jenis dan khasiatnya. Terdapat sekitar puluhan ribu jenis tumbuhan yang keberadaanya tersebar diseluruh wilayah Indonesia dan beberapa diantaranya diketahui memiliki hasiat sebagai tumbuhan obat, salah satunya yaitu daun babadotan (Ageratum conyzoides.). Babadotan (Ageratum conyzoides) merupakan tanaman yang tumbuh liar di tepi jalan, perkarangan dan tanah lapang. Keberadaannya tanaman ini sering disebut sebagai gulma karena manfaat klinisnya belum banyak diketahui oleh masyarakat. Tumbuhan ini memiliki senyawa aktif yaitu saponin flavonoid dan polifenol diketahui memiliki aktivitas antibacterial khususnya untuk menghambat perkembangan bakteri patogen (Magdalena dkk., 2013).

Usaha peternakan ayam broiler memiliki prospek yang baik untuk 
dikembangkan karena konsumsi daging ayam broiler yang mengalami peningkatan untuk beberapa tahun ke depan. Namun, masih banyak peternak yang mengabaikan lingkungan sekitar, sehingga dapat menimbulkan terjadinya penyebaran virus dan bakteri di lingkungan sekitar. Penyebab kerugian dalam usaha ayam broiler disebabkan oleh waktu panen yang lama, bobot badan yang tidak sesuai dengan standar, tingkat kematian yang tinggi dan lainlain. Oleh sebab itu peternak ayam broiler harus dapat mengetahui komponen keberhasilan dan upaya pencegahan penyebaran virus dan bakterei yang dapat meningkstksn presentase kegagalan dalam usaha ayam broiler.

Desinfektan merupakan bahan kimia yang digunakan untuk menghindari terjadinya pencemaran dari bakteri dan virus jasad renik. Tujuan dari penyemprotan desinfektan yaitu untuk membasmi bibit penyakit yang masih tersisa di dalam kandang dan lingkungan sekitar (Badriyah, 2013). Desinfektan yang digunakan oleh peternakan biasanya berupa desinfektan sintesis yang mengandung bahan-bahan kimia sintesis. Pengembangan desinfektan berbahan dasar herbal lokal yang efektif, aman, dan ramah lingkungan perlu dilakukan. Oleh karena itu penelitian ini bertujuan untuk mengetahui pengaruh penggunaan "Babadotan Desinfektan" terhadap infeksi mikroorganisme pada proses produksi di peternakan ayam broiler.

\section{MATERI DAN METODE}

\section{Waktu dan lokasi penelitian}

Penelitian ini dilaksanakan pada tanggal 29 April sampai dengan 28 Mei 2017. Di kandang panggung Teaching Farm Fakultas Peternakan dan Pertanian Universitas Diponegoro, Semarang.

\section{Materi penelitian}

Materi yang digunakan dalam penelitian ini adalah 90 ekor ayam Broiler strain Lohmann MB-202 diperoleh dari PT. Japfa Comfeed Indonesia, ekstrak daun babadotan (Ageratum conyzoide) dan desinfektan komersil Rodalon. Kandang yang digunakan yaitu kandang litter sebanyak 9 petak dengan ukuran tiap petak panjang x lebar $\mathrm{x}$ tinggi $(100 \mathrm{x} 100 \mathrm{x}$ 50) $\mathrm{cm}$ dengan tiap petak kandang diisi 10 ekor ayam.

\section{Metode penelitian}

Metode yang digunakan pada penelitian ini adalah percobaan dengan Rancangan Acak Lengkap (RAL) tiga perlakuan tiga ulangan $(3 \times 3)$. Sembilan puluh ekor ayam DOC dalam penelitian ini dibagi menjadi tiga kelompok tiga ulangan dengan perlakuan berupa penggunaan desinfeksi kandang sebelum chick in dan selama pemeliharaan menggunakan larutan antiseptic yang berbeda, yaitu BANDIT (Babadotan Desinfektan) berbahan dasar eksrak babadotan dan desinfektan sintetis (Rodalon) sebagai berikut:

T1 : Desinfektan Rodalon 1,5\% (1,5 $\mathrm{ml}$ desinfektan Rodalon $+998,5 \mathrm{ml}$ aquades)

T2 : BANDIT 1\% (10 gr ekstrak daun babadotan +1 liter aquades)

T3 : BANDIT 1,5\% (15 gr ekstrak daun babadotan +1 liter aquades)

Perlakuan desinfeksi dilakukan pada saat persiapan chick in dan selama pemeliharaan, desinfeksi juga dilakukan pada tempat pakan dan minum dengan konsentrasi yang sama dengan perlakuan pada desinfeksi kandang. Parameter yang diamati meliputi pertambahan bobot badan (g/ekor) dan konsumsi pakan (g/ekor) dan konversi pakan/ feed conversion rate (FCR). 
Tahapan penelitian adalah sebagai berikut:

\section{Pembuatan ekstrak daun babadotan}

Daun babadotan dibersihkan, dipotong, dikeringkan dan dihaluskan hingga menjadi simplisia. Sebanyak 200 g simplisia dimasukkan ke dalam bejana maserasi, kemudian ditambahkan pelarut ethanol 96\% sebanyak 1 liter. Setelah didiamkan selama 48 jam dan diaduk setiap 6 jam, larutan tersebut disaring menggunakan kain kasa sehingga didapatkan hasil filtrat maserasi. Filtrat yang diperoleh dipekatkan menggunakan rotary evaporator pada suhu $50^{\circ} \mathrm{C}$. Ekstrak kemudian diencerkan secara bertingkat menggunakan aquades sesuai perlakuan.

\section{Analisis data}

Pertambahan bobot badan (PBB) dan konversi ransum dapat dihitung dengan rumus menurut Anang (2007) sebagai berikut:

\section{Pertambahan bobot badan}

$$
\mathrm{PBB}=\frac{\mathrm{BB} \mathrm{t}-(\mathrm{BB} \mathrm{t}-1)}{\Delta}
$$

Keterangan:

$\begin{aligned} \text { PBB } & =\text { Pertambahan bobot badan } \\ & \text { (g/ekor) } \\ \text { BB t } & =\text { Pertambahan bobot badan } \\ & \text { waktu } \mathrm{t} \text { (g/ekor) } \\ \text { BB t- } 1 & =\text { Pertambahan bobot badan } \\ & \text { sebelumnya (g/ekor) }\end{aligned}$

\section{Konversi ransum}

FCR $=\frac{\text { Jumlah komulatif ransum }}{\text { Bobot badan ayam }}$

Data yang diperoleh dianalisis menggunakan SPSS untuk mengetahui signifikansi perlakuan. Data tersebut juga diolah menggunakan metode uji Beda Nyata Terkecil (BNT) untuk mengetahui perbedaan nyata antara perlakuan (Sugiyono, 2010).

\section{HASIL DAN PEMBAHASAN}

Perlakuan desinfeksi kandang dengan menggunakan desinfektan herbal merupakan salah satu cara yang efektif dan aman untuk mencegah terjadinya penyebaran bakteri, virus dan penyakit yang terdapat di dalam sekitar lingkungan kandang sehingga dapat menurunkan angka kematian (mortalitas dan morbiditas) pada ayam broiler.

Hasil penelitian ini menunjukkan bahwa perlakuan desinfeksi kandang menggunakan desinfektan herbal dari ekstrak daun babadotan dan desinfektan sintetis tidak berpengaruh nyata $(\mathrm{P}<0,05)$ terhadap pertambahan bobot badan dan nilai konversi ransum. Hasil penelitian tentang pengaruh desinfeksi herbal menggunakan daun babadotan terhadap pertambahan bobot badan dan nilai koversi ransum dapat dilihat pada Tabel 1. sebagai berikut:

Tabel 1. Pengaruh perlakuan pemberian desinfektan dari daun babadotan terhadap pertambahan bobot badan harian dan nilai konversi ransum pada ayam broiler

\begin{tabular}{|c|c|c|c|}
\hline \multirow{2}{*}{ Parameter } & \multicolumn{3}{|c|}{ Perlakuan } \\
\cline { 2 - 4 } & $\mathrm{T} 1$ & $\mathrm{~T} 2$ & $\mathrm{~T} 3$ \\
\hline FCR & 1,63 & 1,6 & 1,67 \\
\hline PBBH (g/ekor/hari) & 32,75 & 35,11 & 33,69 \\
\hline
\end{tabular}

Keterangan: non-significant $(\mathrm{P}<0,05)$ 
Pada tabel 1 terlihat bahwa pada perlakuan pertama dengan desinfeksi menggunakan desinfektan sintetis dengan konsentrasi $1,5 \%$ selama pemeliharaan ayam broiler sampai periode panen memiliki pertambahan bobot badan sebesar 32,75 g/ekor/hari dengan nilai FCR sebesar 1,63 sedangkan untuk perlakuan kedua dan ketiga menggunakan desinfektan herbal dari ekstrak daun babadotan dengan konsentrasi $1 \%$ dan $1,5 \%$ memiliki pertambahan bobot badan berturut - turut sebesar 35,11 g/ekor/hari dan 33,69 g/ekor/hari.

\section{Pengaruh pertambahan bobot badan terhadap penggunaan desinfektan herbal dan sintetis}

Nilai pertambahan bobot badan harian pada ayam broiler setelah perlakuan desinfeksi menggunakan desinfektan herbal dan sintetis ditampilkan dalam Tabel 1. Hasil ekstrak daun babadotan pada konsentrasi $1 \%$ dan $1,5 \%$ memiliki nilai efektifitas yang sama dengan desinfektan sintetis untuk dapat menaikkan nilai pertambahan bobot badan ayam broiler selama 30 hari. Hal tersebut ditunjukkan dengan nilai pertambahan bobot badan yang sama antara kelompok desinfeksi ekstrak daun babadotan (T2 dan T3) dengan kelompok desinfeksi sintetis (T1) $(\mathrm{P}<0,05)$. Menurut Fahrudin dkk. (2016) bahwa pertambahan bobot badan diperoleh dari perbandingan antara selisih dari bobot akhir dan bobot awal dengan lamanya pemeliharaan. Qurniawan (2016) berpendapat bahwa faktor yang berpengaruh pada pertambahan bobot badan yaitu perbedaan jenis kelamin, konsumsi pakan, lingkungan, bibit dan kualitas pakan. Uzer dkk (2013) bahwa pertambahan bobot badan sangat berkaitan dengan pakan, dalam hal kuantitas yang berkaitan dengan konsumsi pakan apabila kon- sumsi pakan terganggu maka akan mengganggu pertumbuhan.

\section{Pengaruh nilai FCR (Feed Convertion Rate) terhadap penggunaan desin- fektan herbal dan sintetis.}

Hasil nilai FCR (Feed Conversion Rate) pada pemeliharaan ayam broiler selama 30 hari menunjukkan bahwa desinfektan yang berasal dari ekstrak daun babadotan memiliki kemampuan yang sama dengan desinfektan sintetis terhadap nilai FCR selama pemeliharaan. Hal tersebut dapat diketahui dari nilai FCR dari yang tidak berbeda nyata $(\mathrm{P}<0,05)$ antara kelompok desinfektan dari ekstrak daun babadotan (T2 dan T3) dengan kelompok desinfektan sintetis (T1). Nilai FCR merupakan perbandingan antara konsumsi pakan dengan pertambahan bobot badan yang diperoleh dalam jangka waktu tertentu, FCR dapat digunakan untuk mengukur produktivitas ternak. Menurut Allama dkk. (2012) bahwa nilai konversi pakan yang rendah menunjukkan bahwa efisiensi penggunaan pakan yang baik, karena semakin efisien ayam mengkonsumsi pakan untuk memproduksi daging. Indeks konversi ransum akan naik apabila hubungan antara jumlah energi dalam formula dan kadar protein disesuaikan secara teknis (Mookiah et al., 2014). Nilai konversi ransum dipengaruhi oleh jumlah konsumsi ransum dan pertambahan bobot badan (Usman, 2009; Zuidhof et al., 2014). Faktor lain yang dapat mempengaruhi nilai FCR yaitu kualitas day old chick (DOC), kualitas nutrisi, manajemen pemeliharaan dan kualitas kandang (Fontana et al., 1992; Andriyanto et al., 2015)

Penelitian ini menunjukkan bahwa hasil perbandingan antara desinfeksi kandang menggunakan desinfektan dengan ekstrak daun babadotan dan sintetis tidak menunjukkan 
pengaruh yang nyata $(\mathrm{P}<0,05)$ terhadap nilai pertambahan bobot badan dan nilai FCR.

\section{KESIMPULAN}

Berdasarkan hasil penelitian dapat disimpulkan bahwa pemberian desinfektan sintetis dan desinfektan herbal tidak berpengaruh terhadap pertambahan bobot badan dan nilai FCR pada ayam broiler selama proses pemeliharaan.

\section{UCAPAN TERIMAKASIH}

Terimakasih diucapkan kepada Direktorat Penelitian dan Pengabdian Masyarakat, Kementerian Pendidikan Nasional atas Hibah Penelitian pada Skema Program Kreativitas Mahasiswa tahun 2017.

\section{DAFTAR PUSTAKA}

Allama, H., O. Sofyan, E. Widodo dan H. S. Prayogi. 2012. Pengaruh penggunaan tepug ulat kandang (Alphitobius diaperinus) dalam pakan terhadap penampilan produksi ayam pedaging. J. Ilmu - Ilmu Peternakan. 22 (3): $1-8$.

Anang, A. 2007. Panen ayam kampung dalam 7 minggu. Cetakan 1. Penebar Swadaya, Jakarta.

Andriyanto, A. S. Satyaningtijas, R. Yufiadri, R. Wulandari, V. M. Darwin dan S. N. A. Siburian. 2015. Performan dan kecernaan pakan ayam broiler yang diberi hormon testosteron dengan dosis bertingkat. J. Acta Veterinaria Indonesiana. 3 (1): 29-37.
Badriyah, N. dan M. Ubaidillah. 2013. Pengaruh frekuesi penyemprotan desinfektan pada kandang terhadap jumlah kematia ayam broiler. J. Ternak. 4 (2): 22-26.

Fahruddin, A., W. Tanwirah, H. Indrijani. 2016. Konsumsi ransum, pertambahan bobot badan dan konversi ransum ayam lokal di Jimmy's Farm Cipanas Kabupaten Cianjur. Fakultas Peternakan, Universitas Padjadjaran.

Fontana, E.A., W.D. Weaver, B.A. Watkins, and D.M. Denbow. 1992. Effect of early feed restriction on growth, feed conversion and mortality in broiler chicken. Poult. Sci. 71(8):1296-1305.

Magdalena, S., G. H. Natadiputri, F. Nailufar dan T. Purwadaria. 2013. Pemanfaatan produk alami sebagai pakan fungsional. J. Wartazoa. 23 (1): 31-40.

Mookiah, S., CC. Sieo, K. Ramasamy, N. Abdullah, and Y.W. Ho. 2014. Effect of dietary prebiotic, probiotic and synbiotics on performance, caecal bacterial populations and caecal fermentation concentrations of broiler chicken. J. Sci. Food Agric. 94(2):341-348.

Qurniawan, A. 2016. Kualitas daging dan performa ayam broiler di kandang terbuka pada ketinggian tempat pemeliharaan yang berbeda di Kabupaten Takalar Sulawesi Selatan. Program Pascasarjana, Institut Pertanian Bogor. (Tesis). 
Sugiyono. 2010. Statistika untuk Penelitian. Bandung, Alfabeta.

Usman. 2009. Pertumbuhan ayam buras periode grower melalui pemberian tepung biji buah merah (Pandanus conoideus LAMK) sebagai pakan alternatif. Prosiding Seminar Nasional Teknologi Peternakan dan Veteriner. Balai Pengkajian Teknologi Pertanian Papua.

Uzer, F., N. Iriyanti dan Roesdiyanto. 2013. Penggunaan pakan fungsional dalam ransum terhadap konsumsi pakan dan pertambahan bobot badan ayam broiler. J. Ilmiah Peternakan. 1 (1): 282-288.

Zuidhof, M.J., BL. Scheider, V.L. Carney, D.R. Korver, and F.E. Robinson. 2014. Growth, efficiency and yield of commercial broilers from 1957, 1978 and 2005. Poult. Sci. 93(12): 29702982. 